\title{
SENSY OBIEKTYWNOŚCI. Henri Poincaré i Ernst Cassirer W KONTEKŚCIE REALIZMU STRUKTURALNEGO ${ }^{1}$
}

\author{
- Damian Luty -
}

\begin{abstract}
Abstrakt: Celem artykułu jest częściowe uzasadnienie negacji tezy, którą nazywam tezą o genezie realizmu strukturalnego. Dotyczy ona postulowanych w obrębie pewnej metafilozoficznej narracji związków między współczesnymi stanowiskami zwanymi epistemicznym realizmem strukturalnym i ontycznym realizmem strukturalnym, a poglądami filozofów z początku XX wieku. W artykule rekonstruuję wymienione dwa stanowiska, postulowane związki, jakie mają one mieć $\mathrm{z}$ dwoma filozofami, Henri Poincarém oraz Ernstem Cassirerem, a następnie przedstawiam, dlaczego te postulowane związki są nietrafnie rozpoznane. Niesie to za sobą wnioski dotyczące swoistości wymienionych stanowisk oraz pojęć obiektywności i rzeczywistości w ich kontekście.

Słowa kluczowe: Henri Poincaré, Ernst Cassirer, epistemiczny realizm strukturalny, ontyczny realizm strukturalny, konwencjonalizm, idealizm, realizm, obiektywność.

Published online: 7 March 2020
\end{abstract}

\section{Wprowadzenie}

W pracach obrońców realizmu strukturalnego, stanowiska niewątpliwie stale rozwijającego się wskutek krytyki oraz argumentów formułowanych na rzecz kolejnych jego wersji, przewija się metafilozoficzna teza ${ }^{2}$, którą nazywam tezą o genezie realizmu strukturalnego. W trybie rekonstrukcyjnym przedstawiam ją następująco: status współczesnego realizmu strukturalnego jako wartościowego nurtu filozoficznego oparty jest na autorytecie wybranych myślicieli, tworzących, do niedawna nierozpoznaną, strukturalistyczną tradycję ${ }^{3}$. Autorytety przy-

\footnotetext{
Damian Luty

Instytut Filozofii UAM

ul. Szamarzewskiego 89c

60-568 Poznań

e-mail: damianluty@gmail.com

${ }^{1}$ Publikacja finansowana z grantu Narodowego Centrum Nauki w Krakowie, nr rej. grantu 2016/23/N/HS1/00531. Damian Luty jest stypendystą Fundacji Uniwersytetu im. Adama Mickiewicza w Poznaniu na rok akademicki 2017/2018.

2 Esfeld, Lam (2008): 31, zob. Dziekan (2014).

${ }^{3}$ Teza ta jest obecna w jakiejś postaci chociażby w następujących tekstach: Worrall (1989/1996), Ladyman (1998), French (1998), Gower (2000), French, Ladyman (2003), French (2014), McArthur (2007), Votsis (2012).
} 
woływane w tym kontekście to Henri Poincaré, Ernst Cassirer, Moritz Schlick, Pierre Duhem, Hermann Weyl, Arthur Eddington.

Celem mojego artykułu jest częściowe uzasadnienie negacji powyższej tezy. Zamierzam to uczynić poprzez pokazanie nietrafności interpretacji dzieł niektórych z wymienionych postaci, dokonywanych z perspektywy współczesnych realizmów strukturalnych ${ }^{4}$. Spośród podanych myślicieli wybieram dwóch - Poincarégo i Cassirera ${ }^{5}$. W pierwszej części tekstu dokonam rekonstrukcji epistemicznego realizmu strukturalnego (epistemic structural realism, ESR) i przedstawię, w jaki sposób łączone są z nim poglądy Poincarégo. W drugiej skupię się na krytyce tego związku. W trzeciej scharakteryzuję stanowisko ontycznego realizmu strukturalnego (ontic structural realism, OSR) i omówię, jak koncepcja Cassirera jest z nim łączona, natomiast w czwartej dokonam krytyki tego związku.

\section{Epistemiczny realizm strukturalny a Poincaré}

ESR można scharakteryzować, wymieniając jego zasadnicze tezy:

(1) Istnieje świat niezależny od stanów mentalnych podmiotów poznających.

(2) Natury/esencje/własności wewnętrzne obiektów są niepoznawalne.

(3) Poznawanie świata ograniczone jest do odkrywania struktur.

Teza 1 ESR wyraża nastawienie realistyczne. Tezy 2 i 3 wymagają doprecyzowania, którego dokonuje się poprzez określenie dwóch typów ESR ${ }^{6}$. Typ I to ESR „oddolny" (the upward path), typ II to ESR "odgórny” (the downward path). Typ I wiązany jest z przyczynową teorią percepcji Bertranda Russella7. Punktem wyjścia jest tutaj relacja poznawcza między podmiotem a światem zewnętrznym, na podstawie której stwierdza się coś o strukturze świata ${ }^{8}$. Ten typ ESR nie będzie mnie tutaj zajmować. Typ II ESR

\footnotetext{
${ }^{4}$ Zob. Psillos (2015): 8.

${ }^{5}$ Ten ograniczony wybór jest powodem, dla którego uzasadnienie negacji tezy o genezie realizmu strukturalnego ma tutaj charakter częściowy.

${ }^{6}$ Psillos (2009): 125, Votsis (2005): 1363.

7 Russell (1927/2007): 265.

${ }^{8}$ Rezultatami poznania są tutaj percepty, które mają charakter wiedzy bezpośredniej. Nie czyni się w tym kontekście żadnych metafizycznych założeń dotyczących tego, co jest przedmiotem wiedzy, tj. nie stwierdza się niczego na temat tego, jakie są indywidua i ich własności. Ze względu na to, że w teorii Russella percepty są rezultatami przyczynowych procesów, których początek tkwi w świecie zewnętrznym, to mimo subiektywnego charakteru perceptów, możemy na ich podstawie wnioskować o tym, jaki jest świat zewnętrzny. Wiąże się to jednak z ograniczeniem nałożonym przez Russella na takie poznanie. Możemy mianowicie, jak sądził Russell, odwzorować w strukturze naszych perceptów strukturę świata, ale nic poza tym. Russell sformułował dwie zasady mające rządzić takim poznaniem: zasadę Helmholtza-Weyla, głoszącą, że odmienne efekty (np. w postaci perceptów) oznaczają odmienne przyczyny, oraz zasadę odzwierciedlania relacji, która głosi, że relacje między perceptami mają takie same własności logiczne, co relacje między niementalnymi przyczynami perceptów. Postulat izomorfizmu między strukturami perceptów a strukturami przyczyn perceptów i ograniczenia przedmiotu poznania do struktur oznacza, że o świecie zewnętrznym możemy wiedzieć tylko, jakie są jego własności drugiego rzędu (własności relacji). Zasadniczy zarzut formułowany przeciwko tej postaci realizmu strukturalnego to tzw. zarzut Newmana. Upraszczając, w zarzucie tym wykazuje się, że realizm strukturalny omawianego typu jest stanowiskiem albo trywialnym, albo fałszywym: Newman (1928): 144; Demopoulus, Friedman (1985): 633; Ainsworth (2009): 145.
} 
wywodzony jest bezpośrednio od Poincarégo. Głównym zagadnieniem jest w nim ciągłość nauki na poziomie teoretycznym. W tym kontekście teza 2 wyraża po prostu tyle, że terminy teoretyczne niczego nie reprezentują, natomiast teza 3 oznacza rozumienie struktury jako układów równań odzwierciedlających rzeczywiste związki między zjawiskami zachodzącymi w świecie9. Typ II ESR wprowadzony został przez Johna Worralla $\mathrm{w}$ ramach teoriopoznawczego sporu realizmu $\mathrm{z}$ antyrealizmem/instrumentalizmem ${ }^{10}$. ESR miał stanowić wersję realizmu, za którą przemawia zarówno przedstawiony przez realistów argument $\mathrm{z}$ cudu ${ }^{11}$, jak i oparty na historycznych świadectwach argument z pesymistycznej meta-indukcji wysuwany przez antyrealistów ${ }^{12}$ :

Zaszło przejście, zachowujące ciągłość międzyteoretyczną, między teoriami światła Frensela i Maxwella, lecz ciągłość ta dotyczy formy czy struktury, nie treści. Co więcej, takie twierdzenie postawił i bronił go Poincaré. Poincaré użył przykładu przejścia od Fresnela do Maxwella, argumentując na rzecz ogólnej postaci syntaktycznego czy strukturalnego realizmu... Ta w dużej mierze zapomniana teza Poincarégo wydaje mi się wskazywać jedyną dobrze rokującą drogę do tego, by zarazem umocnić argument z cudu, jak i przyjąć stosowne stanowisko w odniesieniu do teoretycznych zmian $w$ nauce ${ }^{13}$.

Worrall twierdził zatem, odnosząc się do Poincarégo, że w nauce panuje ciągłość teoretyczna, lecz ciągłość ta nie jest ugruntowana w stałości desygnatów terminów teoretycznych, tylko w stałości określonych równań matematycznych.

Na jakiej podstawie przypisywać można Poincarému tezę na kształt tezy 1 ESR? Poincaré, w kontekście dyskusji ${ }^{14}$ z przełomu XIX i XX wieku wokół „bankructwa nauki”, przeciwstawił się instrumentalistycznym interpretacjom swojego konwencjonalistycznego stanowiska w filozofii geometrii, zaproponowanym przez Edouarda Le Roy ${ }^{15}$. Le Roy sądził, że z niestabilności nauki należy wyprowadzić radykalnie instrumentalistyczny na nią pogląd - powoływał się w tym miejscu właśnie na konwencjonalistyczne podejście Poincarégo do geometrii ${ }^{16}$. Dla Poincarégo takie wykorzystanie jego konwencjonali-

\footnotetext{
9 Relacja między tezą 2 a tezą 3 ESR występuje w literaturze jako zagadnienie dualizmu natury i struktury. Stało się ono przedmiotem krytyki (Psillos (1999): 149), zgodnie z którą niemożliwy jest jednoznaczny podział treści poznawczych na treści dotyczące „natur" obiektów i na treści strukturalne. Psillos sądził, że taki podział jest nieodzowny dla poprawności ESR. Krytyka Psillosa została jednak podważona przez Chakravartty'ego (2007: 43). Chakravartty stwierdził, w ramach stanowiska nazwanego semirealizmem, że zgadzając się na wyrażenie przyczynowych własności monadycznych obiektów poprzez wskazanie na ich własności dyspozycyjne, można uznać, że dyspozycje te przejawiają się różnie, w zależności od kontekstu. Wówczas relacje, w jakie dany obiekt wchodzi, pozwalają rozpoznać daną własność dyspozycyjną. W tym sensie, chociaż natura i struktura nie są tutaj w pełni odseparowane, treści strukturalne są odróżnione funkcjonalnie od treści dotyczących natur.

${ }^{10}$ Worrall (1989/1996): 140-141.

11 Putnam (1975): 73, Musgrave (1988): 239.

${ }^{12}$ Laudan (1981): 24.

${ }_{13}$ Worrall (1989/1996): 157, tłum. D.L.

${ }^{14}$ MacLeod (1982).

${ }^{15}$ Ivanova (2015): 115.

16 Poincaré (1898).
} 
zmu stanowiło nadużycie, Poincaré bowiem wierzył w obiektywność nauki. Uważał, że instrumentalizm i powiązany z nim konstruktywizm głoszący, że "fakt” jest wtórny względem arbitralnie przyjętej teorii i uwarunkowań podmiotu, są błędne. Aktywność podmiotu ludzkiego nie polega na wytwarzaniu faktów, ale na doborze faktów zastanych $^{17}$, co więcej „(...) fakty pozostaną faktami i jeżeli tak się zdarzy, że zdołamy je przewidzieć, to nie jest to rezultat naszej nieskrępowanej niczym aktywności"18. Przynajmniej w kontekście samych podstaw nauki, Poincaré uważał, że istnieją surowe fakty, które są nieredukowalne do czegokolwiek innego ${ }^{19}$. W kontekście dyskusji z Le Roy i przeciwko instrumentalistycznemu i naiwnie konstruktywistycznemu podejściu Poincaré stwierdza:

Czym zatem jest nauka? (...) Jest to, nim dokona się jakichkolwiek klasyfikacji, sposób kojarzenia faktów mających zróżnicowane przejawy, jak gdyby były one połączone jakimś naturalnym i ukrytym pokrewieństwem. Nauka, innymi słowy, jest systemem relacji. (...) Powiedzieć, że nauka nie posiada obiektywnej wartości skoro poucza nas jedynie o relacjach, to rozumować wstecz, skoro właściwie jest tak, że to same relacje należy uznać za obiektywne ${ }^{20}$.

Ponadto, jak zauważa Szlachcic ${ }^{21}$, w pismach Poincarégo ${ }^{22}$ znaleźć można trzy sposoby rozumienia pojęcia prawdy: a) jako idei regulującej działania poznawcze realizowane przez społeczność naukowców; b) jako zgodności bądź niezgodności fragmentów wiedzy ze sobą; c) jako rozstrzygalności kwestii kwalifikacji prawdziwościowej praw i teorii nauk empirycznych. Jest zatem jasne, że Poincaré nie odrzuca zagadnienia prawdy naukowej, ale jedynie je problematyzuje, wskazując różne jego aspekty w kontekście praktyki badawczej. Poza odnoszeniem się teorii do świata (punkt c) istotne jest przecież to, aby teorie były wewnętrznie spójne i w tym kontekście można postulować relacyjne rozumienie prawdy, o czym mowa w punkcie b). Można wreszcie rozumieć prawdę jako wartość moralną ${ }^{23}$, zgodnie z punktem a) ${ }^{24}$. Problematyzacja kwestii prawdy to za mało, aby uznać, że Poincarému można przypisać instrumentalistyczną orientację w jego wersji stanowiska konwencjonalistycznego. Obronę obiektywności nauki w sporze z Le Roy oraz podejście do zagadnienia prawdy naukowej można potraktować jako wystarczające do odrzucenia instrumentalizmu w kontekście tezy 1 . W związku z tym, jak się wydaje, istnieje racja do mówienia o jakiejś słabej postaci realizmu u Poincarégo ${ }^{25}$.

Teza 2 ESR przypisywana jest Poincarému na podstawie następującego cytatu:

\footnotetext{
17 Poincaré (1905/1958): 122, tłum. D.L.

18 Ibidem: 127.

19 Poincaré (1905/1958): 126.

20 Ibidem: 142, tłum. D.L.

21 Szlachcic (2011): 349-350.

22 Oraz w pismach innego twórcy konwencjonalizmu - P. Duhema.

23 Szlachcic (2011): 350.

24 Do ujmowania prawdy, w kontekście myśli Poincarégo, jako wartości moralnej szczególnie skłaniać może wprowadzenie do książki Wartość nauki - Poincaré (1905/1958): 11, Szlachcic (2011): 350.

25 Psillos (2014): 18, zob. Szlachcic (1992).
} 
Niech nikt nie sądzi, że oto sprowadzamy teorie fizyczne do roli zaledwie praktycznych wskazówek; te równania wyrażają relacje i jeśli równania pozostaną prawdziwe to dzieje się tak, ponieważ relacje zachowują swoją realność. Dzięki równaniom możemy, tak teraz jak i kiedyś, nauczyć się, że istnieje taka a taka relacja między czymś jednym a czymś drugim; tylko że kiedyś to jedno coś nazywaliśmy ruchem a teraz zwiemy prądem elektrycznym. Lecz te nazwy były tylko obrazami, które podstawiane były za rzeczywiste obiekty, których natura na zawsze pozostanie przed nami ukryta. Prawdziwe relacje między tymi rzeczywistymi obiektami są jedyną osiągalną przez nas rzeczywistością i jedynym warunkiem jest to, żeby te same relacje zachodziły zarówno między tymi obiektami jak i między obrazami, którymi zastępujemy obiekty. Jeśli te relacje są nam znane, jakież to ma znaczenie, jeżeli uznamy za wygodne wymienianie jednych obrazów innymi ${ }^{26}$.

Tezę 3 ESR można przypisać Poincarému pod wpływem interpretacji przedstawionej przez Jerzego Giedymina ${ }^{27}$. Dla Giedymina konwencjonalizm Poincarégo w odniesieniu do fizyki i wykorzystywanych w niej aparatów formalnych wynikał z założenia przezeń koncepcji „fizyki zasad”, w której mówi się o pewnym zbiorze empirycznych uogólnień, z których część zostaje wyniesiona do rangi zasad. Należy przez to rozumieć, że od pewnego momentu historycznego rozwoju fizyki do zasad przestały być odnoszone dalsze świadectwa empiryczne ${ }^{28} \mathrm{i}$ w rezultacie do zasad tych nie stosuje się dychotomia prawdy i fałszu ${ }^{29}$. Jako przykłady takich zasad Poincaré podaje ${ }^{30} \mathrm{~m}$.in. zasady zachowania masy i energii czy zasadę najmniejszego działania ${ }^{31}$. Co ważne, jak sądził Poincaré, w obliczu kryzysu zasad nigdy nie jest tak, że unieważnieniu ulegają wszystkie zasady. Te zasady, które przetrwają (oczywiście, ulegając pewnym modyfikacjom, np. w ich postaci formalnej) konstytuują ciągłość nauki na poziomie teoretycznym, poza zwykłym, ciągłym przyrostem danych empirycznych ${ }^{32}$.

Giedymin przypisując koncepcji fizyki opartej na zasadach centralną rolę w podstawach filozofii nauki Poincarégo starał się przede wszystkim wykazać, że jego konwencjonalizm w odniesieniu do mechaniki nie ma charakteru instrumentalistycznego, jak sądził choćby K. Popper, oraz że konwencjonalizm ten nie jest skrajny. Zasady, choć odwoływalne, ugruntowane są w faktach, a Poincaré, jak widać było w jego dyskusji z Le Roy, uznaje istnienie surowych, nietworzonych dowolnie przez podmiot faktów. Giedymin pisze dalej:

(...) według Poincarégo, równania tworzące abstrakcyjną część teorii fizycznej współokreślają jej zawartość nie tylko ze względu na konsekwencje obserwacyjne teorii, ale również ze względu na samą postać tych równań, wykorzystaną do przedstawienia

\footnotetext{
${ }^{26}$ Poincaré (1902/1905): 161, tłum. D.L.

27 Giedymin (1982): XI.

28 Poincaré (1902/1905): 138.

${ }^{29}$ Giedymin (1982): 27, zob. Poincaré (1905/1958): 93.

${ }^{30}$ Poincaré (1905/1958): 94

${ }^{31}$ Jedna z zasad wariacyjnych w mechanice. Giedymin zresztą starał się wykazać, że koncepcja fizyki zasad sięga właśnie Hamiltona - Giedymin (1982): 43.

${ }^{32}$ Poincaré (1905/1958): 95.
} 
określonych rozwiązań. Przez postać równań Poincaré rozumiał ich typ (równania różniczkowe zwyczajne lub cząstkowe), rząd i grupę, której transformacje realizuje, tj. względem której równanie jest niezmiennicze. Jeśli dwie teorie są nie tylko równoważne obserwacyjnie, lecz również korzystają z równań o takiej samej postaci, wtedy są one ściśle równoważne. (Można to nazwać konwencjonalistyczna zasada równoważności albo teza strukturalnego realizmu $)^{33}$.

Przykłady, jakie podaje Poincaré, dotyczą zjawisk absorpcji i dyspersji w optyce oraz ich opisu przez odpowiednie równania - równania Fresnela. Te równania zachowały swoją postać (w sensie Poincarégo) w przejściu od teorii Fresnela do teorii Maxwella, a było to możliwe, ponieważ, zdaniem Poincarégo, w tych równaniach różniczkowych uchwycone są rzeczywiste związki zachodzące w świecie oraz prowadzą one do tych samych predykcji empirycznych w przypadku obu rozważanych teorii. Jeżeli zatem w dwóch teoriach uchwycono rzeczywiste związki, prawa w obu teoriach wyrażające te związki będą wzajemnie przekładalne: „prawami niezmiennymi są stosunki między faktami surowymi" ${ }^{34}$. Stosunki między faktami surowymi tworzą "powszechne niezmienniki" (przynajmniej częściowo) równoważnych, choć odmiennych, teorii naukowych. Równania różniczkowe wyrażające takie niezmienne prawa mają być „zawsze prawdziwe" ${ }^{\prime 35}$. W tym sensie, jak sądzę, niezmienniki powszechne mogą sugerować, ze względu na odniesienie do surowych faktów, że dla Poincarégo istnieje jedna, obiektywna rzeczywistość, która może być opisywana w różny sposób ${ }^{36}$.

\section{Krytyka realistyczno-strukturalnej interpretacji Poincarégo: sensy obiektywności}

Podstawą do odrzucenia związków Poincarégo z realizmem może być jego rozumienie zasad jako pewnego mechanizmu samoregulującego charakterystycznego dla nauki ujętej jako przedsięwzięcie określonej społeczności (naukowców). Mimo retoryki Poincarégo, relacji wyrażonych przez równania nie trzeba traktować realistycznie ${ }^{37}$. Nie należy dosłownie traktować wypowiedzi Poincarégo o „prawdziwości równań” jako kwalifikacji prawdziwościowej; jaki zresztą miałyby sens te wypowiedzi, gdyby wziąć je na serio? W jaki sposób same równania matematyczne miałyby być "prawdziwe”? Uważam, że wszystkie wymienione wcześniej sposoby odnoszenia się Poincarégo do prawdy nie dają odpowiedzi na to pytanie, sposoby te dotyczą bowiem całych teorii naukowych i tego, jak są one użytkowane.

Kluczowym, jak sądzę, punktem wyjścia dla realistyczno-strukturalnej interpretacji Poincarégo jest przeprowadzona przezeń obrona obiektywności nauki. Jednakże u Poincarégo termin „obiektywność” nie jest koekstensywny z terminem „rzeczywistość”.

\footnotetext{
${ }^{33}$ Giedymin (1982): 83, tłum. D.L., kursywa - D.L.

${ }^{34}$ Poincaré (1902/1958): 129.

35 Poincaré (1902/1905): 161.

${ }^{36}$ Zwolennicy ESR nie odwołują się, według mojej wiedzy, do pojęcia "niezmiennika powszechnego", ale rozszerzenie wywodu dotyczącego ewentualnej kompatybilności myśli Poincarégo z ESR o wspomniane pojęcie wydaje się zasadne, ponieważ jednoznacznie mowa w jego kontekście o relacjach (stosunkach).

${ }^{37}$ Brading, Crull (2017): 113.
} 
Poincaré stwierdza: „To, co zwiemy obiektywnością jest (...) wspólne wielu myślącym bytom i może być wspólne im wszystkim; ta wspólna im część (...) może jedynie być harmonią wyrażaną przez matematyczne prawa" ${ }^{38}$. Stąd należałoby twierdzić, że obiektywność u Poincarégo właściwie jest tożsama z intersubiektywnością ${ }^{39}$. W szczególności, niedesygnowanie terminów teoretycznych wiąże się z podkreślanym przez Poincarégo aspektem twórczym praktyki naukowej, który polega na postulowaniu istnienia takich a takich bytów. Toteż teza 2 ESR powierzchownie i błędnie oddaje intencje Poincarégo.

Koncepcja faktów surowych w ujęciu Poincarégo również nie sprzyja realistycznym interpretacjom jego poglądów. Pojęcie faktu surowego należy do teorii genezy myślenia naukowego i nie służy umocowaniu odniesienia teorii naukowej do świata. Poincaré, owszem, sądził, że istnieją surowe fakty, dzięki którym w eksperymencie można stwierdzić stabilność określonych związków. Nie twierdził, że konstruujemy całkowicie fakty, lecz zarazem uważał, że człowiek wnosi nieusuwalny wkład w funkcjonowanie nauki ${ }^{40}$. Fakty surowe odróżnione są ponadto od faktów naukowych: te pierwsze związane są z codziennym doświadczeniem ${ }^{41}$. Poincaré twierdził, że przejście od tych pierwszych do drugich ma charakter selektywnej idealizacji, która sterowana jest zarówno potocznym doświadczeniem, jak i (rozumianą quasi-kantowsko) intuicją. Przykładem może być jego opis źródeł pojęcia grup przekształceń w geometrii ${ }^{42}$ i w fizyce ${ }^{43}$.

Poincaré twierdzi mianowicie, że pojęcie grupy przekształceń nie mogłoby powstać, gdybyśmy nie mieli kontaktu z ciałami sztywnymi w przyrodzie, które przemieszczają się w sposób ciągły, zachowując swoje własności ${ }^{44}$. O ile nie istnieją w przyrodzie ciała doskonale sztywne, tak umysłowo można to pojęcie uzyskać w drodze idealizacji ${ }^{5}$. Dokonując już w umyśle nieskończonych powtórzeń określonych przemieszczeń, możemy prawa ich składania uogólnić do (naukowo istotnego) pojęcia grupy przekształceń ${ }^{46}$. Ze względu na zachowanie ciał w przybliżeniu sztywnych, dostępnych w potocznym doświadczeniu, najwygodniejszą idealizacją jest ta, która obejmuje grupy przekształceń w przestrzeni euklidesowej. Wprawdzie empiryzm w filozofii geometrii jest, zdaniem Poincarégo, fałszywy, tj. nie istnieje eksperyment pozwalający wybrać jedną z wielu dostępnych geometrii, to jednak nie jest tak, że kryterium wygody w wyborze geometrii jest kryterium arbitralnym - jest ono u Poincarégo osadzone we fragmentach potocznego doświadczenia, które jest wybrane, a następnie poddane intelektualnej obróbce ze względu na pewne wyróżnione zdolności umysłu ${ }^{47}$, głównie ze względu na wspomnianą zdolność do powtarzania w pamięci ${ }^{48}$.

\footnotetext{
38 Poincaré (1905/1958): 14.

39 Brading, Crull (2017): 114.

40 Psillos (2014): 20.

${ }^{41}$ Szumilewicz (1978): 33.

${ }^{42}$ Zahar (1997): 199.

${ }^{43}$ Hilbert, Huggett (2006): 765.

${ }^{44}$ Poincaré (1902/1905): 60-61.

${ }^{45}$ Ibidem: 64.

${ }^{46}$ Możliwość takiego nieskończonego powtarzania leży, według Poincarégo, w intuicyjnie pierwotnej indukcji matematycznej - Poincaré (1905/1958): 23.

${ }^{47}$ Torretti (1984): 320-352.

48 Ben-Menahem (2006): 51-52.
} 
Teza 3 ESR jest ponadto problematyczna ze względu na to, że dla Poincarégo równania, powiązane z zasadami, mają szczególny metodologiczny walor związany z ekonomią myślenia. Równania bowiem „pozwalają nam unikać ciągłego powtarzania (badań) poprzez podanie nam określonego rezultatu z góry" ${ }^{49}$. Ponadto, szerzej rozpatrzona analiza dokonana przez Giedymina, która nie traci z oczu bliskiego związku Poincarégo z umiarkowanym konwencjonalizmem, nie daje podstaw, by Poincarému przypisywać tezę 3 ESR. Wreszcie:

(...) Nie zaszedłbym tak daleko, by twierdzić, że obiektywność sprowadza się do czysto ilościowych określeń (to by prowadziło do zbyt daleko posuniętego ukonkretnienia natury rozważanych relacji), rozumiemy jednakże, że niektórzy mogliby przesadzić i uważać, że świat jest tylko równaniem różniczkowym ${ }^{50}$.

Poglądy Poincarégo na relacje i ich epistemiczną rolę okazują się więc bardzo złożone, uwzględniając perspektywy zarówno quasi-kantowskie (rola intuicji), jak i empirystyczne. Przez to są nieadekwatne względem czysto eksternalistycznej epistemologii związanej z ESR zaproponowanym przez Worralla. Bierze się to zarówno z odmiennego umotywowania poglądów Poincarégo, innego rozumienia terminu "obiektywność”, jak i z wielowątkowości jego poglądów, bardzo dobrze rozpoznanej w literaturze dotyczącej filozofii nauki ${ }^{51}$. Toteż nic dziwnego, że Worrall w swojej późniejszej wersji ESR inspirował się czymś zgoła odmiennym - podejściem Ramseya do teorii naukowych ${ }^{52}$.

\section{Relacyjność fundamentalnych zasad w przyrodoznawstwie według E. Cassirera}

Podobnie jak Poincaré, E. Cassirer wskazywany jest jako jeden z pierwszych filozofów proponujących takie podejście $\mathrm{w}$ interpretowaniu teorii przyrodoznawczych, które przynajmniej częściowo ma charakter strukturalistyczny ${ }^{53}$. Na Cassirera powołują się zwolennicy OSR, tacy jak Steven French ${ }^{54}$ czy James Ladyman ${ }^{55}$.

OSR można scharakteryzować w sposób ogólny następująco:

(1) Istnieje świat niezależny od stanów mentalnych podmiotów poznających.

(2) Obiekty (indywidua) są eliminowalne z ontologii świata fizycznego, przynajmniej na jego fundamentalnym poziomie.

(3) To, co istnieje w świecie, to struktury.

Tezy właściwe OSR, tezy (2) i (3), są kontrowersyjne ${ }^{56}$. Wzięte łącznie, tezy te w kontekście ontologii dopuszczalnej przez zwolenników OSR prowadzą do rozumienia struktury wyłącznie jako zbioru relacji; zbiór elementów interpretowanych jako obiekty będące konkretnymi indywiduami jest zbiorem pustym. Jak jednakże rozumieć samoist-

\footnotetext{
49 Poincaré (1902/1905): 159.

50 Poincaré (1905/1958): 136, tłum. D.L.

51 Zob. np. Sady (2013): 74.

52 Worrall, Zahar (2001); Worrall (2011).

${ }^{53}$ Mormann (2014): 44.

54 French (2014): 87.

55 Ladyman (2007): 140.

56 Por. McKenzie (2017).
} 
ność ontologiczną relacji ${ }^{57}$ ? W świetle odrzucenia standardowego, teoriomnogościowego rozumienia struktury istnieją poważne trudności w wyartykułowaniu stosownej i precyzyjnej charakterystyki struktury w sensie ontologicznym, o który chodzi zwolennikom OSR. Powyższa wersja OSR jest wersją eliminatywistyczną ${ }^{58}$. Późniejsze ujęcia skupiają się na zależności obiektów od struktur i w tym kontekście próbuje się doprecyzować pojęcie struktury, w jednym przypadku bezpośrednio czerpiąc z poglądów Cassirera. French, szkicując odpowiedź na zarzut, że w OSR nie ma dobrze określonego pojęcia struktury, pisze:

Zacznę od wizji Cassirerowskiej (...): zasady symetrii łączą w spójną sieć relacje wyrażane przez sformułowania praw. Jak do tego połączenia dochodzi, oczywiście zależy od pojmowania związku między prawami i symetriami. Mogłoby się zdawać, że poglądy, zgodnie z którymi zasady symetrii są postulatami narzuconymi na formę praw, bądź w niektórych przypadkach bezpośrednio dyktują prawa, lepiej odpowiadają koncepcji łączenia relacji w sieci, niż pogląd, według którego symetrie są „produktami ubocznymi” praw. Jednakże symetrie, nawet gdyby były (tylko) produktami ubocznymi praw, mogłyby pełnić swoją rolę [łączącą], a dokładniej rolę wyższego rzędu funkcji praw ponieważ, jako takie, mogą niejako spinać (span) prawa ze sobą, a zatem działać jako spoiwo struktury. Próby rozstrzygnięcia między tymi poglądami zazwyczaj odwołują się do praktyki naukowej, która tak naprawdę nie jest decydująca. Biorąc to wszystko pod uwagę (...) będę nadal będę utrzymywał za Cassirerem, że między symetriami a prawami zachodzi coś w rodzaju „wzajemnego przeplatania się i powiązania", i że to stąd biorą się jestestwa nazywane dotąd obiektami ${ }^{59}$.

Motywacje stojące za takim ujęciem są związane z tzw. „rekonceptualizacją obiektów" ${ }^{\prime \prime}$, przez którą rozumie się pogląd, że obiekty należy traktować jako narzędzia służące do prezentacji przekształceń symetrycznych w fundamentalnych teoriach naukowych. Natomiast niezmienniki danych przekształceń reprezentują fakty ze świata zewnętrznego. Obiekty w tym kontekście wprowadzane są wyłącznie jako części pewnego sposobu mówienia. French stwierdza, że w kontekście rozumienia nauki przez Cassirera można bronić poglądu, iż „(...) teoria sama «wytwarza» swoje obiekty, oraz obiektywność jest ugruntowana w uniwersalności praw i zasad"61.

French i A. Cei dokonali analizy podejścia Cassirera do mechaniki kwantowej i wskazali elementy istotne, ich zdaniem, dla OSR ${ }^{62}$. Elementy te mają prowadzić do

\footnotetext{
${ }^{57}$ W tym kontekście wysuwa się zarzut o konceptualną absurdalność OSR. Zarzut ten głosi, że w świetle standardowych ujęć teoriomnogościowych, relacje zawsze określone są na obiektach - Chakravartty (2007): 78, Busch (2003): 214. Pełna eliminacja obiektów na rzecz niezapełnionych miejsc wiązanych przez relacje prowadzi ponadto do kolejnego zarzutu, zgodnie z którym w OSR nie da się wskazać różnicy między strukturą abstrakcyjną a strukturą konkretną - Cao (2003): 60, Dorato (2016): 178.

${ }^{58}$ Frigg, Votsis (2011): 261.

${ }^{59}$ French (2014): 264, tłum. D.L. Dziękuję recenzentom za cenne uwagi dotyczące tłumaczenia tego fragmentu.

${ }^{60}$ Ibidem: 44.

${ }^{61}$ French (2014): 99.

${ }^{62}$ French, Cei (2009): 113.
} 
następujących tez: i) relacje są logicznie wcześniejsze od obiektów, ii) obiektywność nie jest powiązana $z$ ontologiczną kategorią obiektów ${ }^{63}$. Obiektywność powiązana jest z symetriami. Należałoby zatem stwierdzić, że przynajmniej w powyższym fragmencie, inspirowanym dziełem Cassirera, struktura w sensie ontologicznym rozumiana jest jako wzajemny związek praw przyrody oraz symetrii. W tej perspektywie obiekty tracą obiektywne istnienie i stają się wyłącznie elementem aparatu matematycznego danej teorii. Postulowanie realnego istnienia obiektów byłoby hipostazowaniem elementów aparatu formalnego, przynajmniej w odniesieniu do części świata opisywanej przez fizykę fundamentalną ${ }^{64}$. Ze względu na centralną rolę przekształceń symetrycznych i postulat realistycznego nastawienia względem treści strukturalnej teorii, tę wersję OSR czasami nazywa się realizmem teoriogrupowym (group-structural realism, GSR). Zarówno prawa, jak i symetrie interpretowane są, rzecz jasna, realistycznie ${ }^{65}$. W tym kontekście należy zapytać, czy daleko idąca inspiracja poglądami Cassirera jest tutaj ścisła czy też zbyt swobodna i czy słuszne jest w przypadku tego myśliciela separowanie jego przekonań dotyczących struktury od neokantowskiego tła.

Cassirer wywodził się z marburskiej szkoły neokantyzmu, w której obiektywność nauki uznawana była za niepodważalny fakt ${ }^{66}$. Zadaniem, jakie postawił przed sobą Cassirer, było wyjaśnienie obiektywności nauki w obliczu pojawienia się odkryć naukowych i matematycznych przeczących doktrynie kantowskiej, przede wszystkim - czystemu a priori i koncepcji czasu i przestrzeni jako form naoczności ${ }^{67}$. Kant usiłował wyjaśnić, jak możliwe jest zmatematyzowane przyrodoznawstwo, za wzór przyjmując fizykę newtonowską, która wraz z powstaniem obu teorii względności oraz fizyki kwantowej zdezaktualizowała się jako fundamentalna teoria przyrodoznawcza i nie można już było jej traktować jako wyrażającej określone raz na zawsze formy naoczności.

Cassirer, tworząc swoje stanowisko, bazował również na rozwoju logiki matematycznej, czerpiąc z wyników Fregego i Russela ${ }^{68}$ oraz z rozwoju matematyki - korzystał zwłaszcza z prac Dedekinda, z teorii szeregów oraz z Erlanger Programm F. Kleina. Centralne pojęcia to pojęcia funkcji oraz relacji. Pozwalają one, jak sądził Cassirer, uniknąć problemów związanych z logiką arystotelesowską, podmiotowo-orzecznikową, z którą wiąże się substancjalne ujęcie rzeczy. Cassirer twierdził, że taki substancjalizm nasuwa przekonanie, że istnieje pewien niezmienny nośnik własności. Nie dysponując już kantowskim czystym a priori w przeprowadzeniu krytyki poznania, negując - w kontekście teorii znaku Helmholtza - możliwość przybliżonego odwzorowywania rzeczy w umyśle, Cassirer uznał, że ugruntowując obiektywność poznania naukowego, należy zwrócić się ku samej relacji między stroną podmiotową i przedmiotową. Cassirer odrzucał jednakże psychologizm, umieszczając po stronie "podmiotowej” aparat matematyczny danej teorii, a po stronie przedmiotowej sytuacje eksperymentalne, czyli pomiary. Między

\footnotetext{
${ }^{63}$ Ibidem.

${ }^{64}$ French, powołując się na Poincarégo, nazwał instrumentalistyczne traktowanie obiektów jako narzędzi reprezentacyjnych „manewrem Poincarégo" - French (2014): 67.

${ }^{65}$ Co stanowi odrębny problem, zob. Van Fraassen (1989), Dasgupta (2015).

${ }^{66}$ Friedman (2005a): 72.

${ }^{67}$ Friedman (2005b): 120.

${ }^{68}$ Gower (2000): 88.
} 
aparatem teoretycznym a sytuacjami eksperymentalnymi zachodzi związek funkcjonalnego przypisania - Zuordnung. Jest ono, wg Cassirera, „logiczną formą (...), poprzez którą różnorodne elementy złączone zostają w systematyczną jedność" ${ }^{69}$. Zuordnung ma charakter nieredukowalnie relacyjnego związku między (daną) teorią a empirią, ma fundamentalny status i pełni rolę transcendentalnej formy rozumienia (a nie naoczności).

Przy takim ujęciu nauki nasuwa się pytanie o cele poznania, które Cassirer charakteryzuje przy pomocy terminów „jedności” i „trwania"70. Przez „jedność" teorii naukowej Cassirer rozumie jej spójność i ustrukturyzowanie poprzez prawa formułowane w tej teorii, przez "trwanie" rozumie to, co niezmiennicze w poznaniu przeprowadzanym z różnych perspektyw. Należy podkreślić, że nie jest tak, iż konkretne prawa przyrody postulowane przez daną teorię są w tym kontekście tożsame z prawami zapewniającymi obiektywność poznania. Cassirer odróżniał stwierdzenia dotyczące pomiarów od stwierdzeń dotyczących praw oraz od stwierdzeń dotyczących zasad ${ }^{71}$. Te ostatnie są najbardziej ogólne i są dla Cassirera właściwym komponentem apriorycznym poznania naukowego. Od tych zasad zależy jego zdaniem powszechna obowiązywalność praw przyrody. Przedmiot poznania jest dla Cassirera „wyrazem formy i sposobu pojmowania"72 i w tym sensie, chociaż przedmiot poznania konstytuowany jest w zależności od kontekstu badawczego poszczególnych teorii przyrodoznawczych, to jest on regulowany na gruncie nauki przez zasady i to one ugruntowują obiektywność poznania naukowego.

Cassirer znajdował przykłady takich zasad, powołując się (tak samo jak Poincaré!) na fizykę zasad:

Od połowy dziewiętnastego stulecia jednakże w miejsce (...) „fizyki materii” coraz bardziej stanowczo i wyraźnie zaczęła wkraczać fizyka zwana „fizyką zasad”. Tutaj nie wychodzi się od hipotetycznego istnienia określonych materii i czynników, lecz od pewnych powszechnych relacji, które są traktowane jako kryteria interpretacji poszczególnych zjawisk. Ogólna teoria względności stoi metodycznie na końcu tego szeregu, ponieważ zbiera wszystkie poszczególne systematyczne zasady w jedność najwyższego postulatu - nie postulatu stałości rzeczy, lecz niezmienności pewnych wielkości i praw wobec wszelkich przekształceń układu odniesienia ${ }^{73}$.

W tym kontekście oraz w kontekście zestawienia z OSR, decydujący jest status zasad prowadzący do odrzucenia „substancjalnych” obiektów jako przedmiotów poznania. Skupię się na przykładzie ogólnej teorii względności. W przypadku tej teorii Cassirer jako egzemplifikację zasady traktował ogólną współzmienniczość, interpretując ją jako uogólnioną zasadę względności ze szczególnej teorii względności, którą rozumiał następująco ${ }^{74}$ :

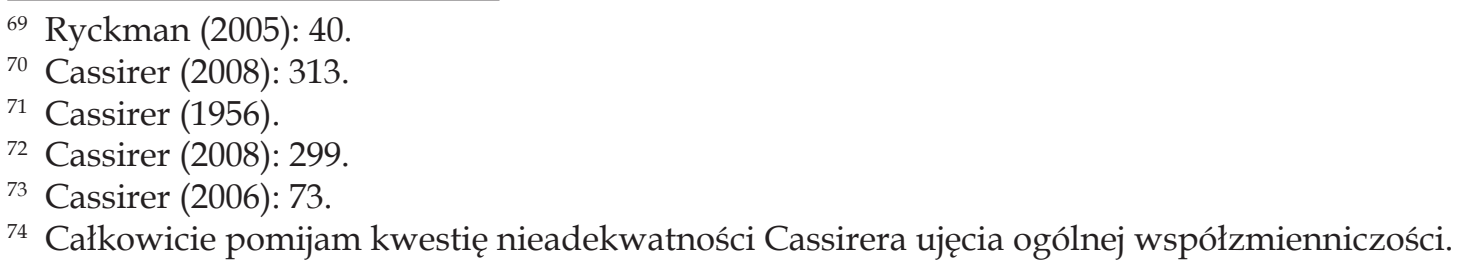


Wraz z żądaniem, aby prawa przyrody były ogólnie współzmiennicze, fizyka dopełniła zmianę z substancjalnego na funkcjonalne - już nie jest tak, że istnienie jednostkowych bytów, określonych trwałości znajdujących się w czasie i przestrzeni, tworzy 'ostateczny poziom obiektywności', lecz raczej [rolę tę pełni] 'niezmienniczość relacji pomiędzy wielkościami'75.

Punkty czasoprzestrzenne natomiast nie mogą być traktowane niezmienniczo, ich określoność zależy wyłącznie od relacji, w jakie wchodzą między sobą ze względu na metrykę danej czasoprzestrzeni pod przekształceniami tworzącymi klasy równoważności ${ }^{76}$. Dlatego punkty czasoprzestrzenne i określone na nich układy współrzędnych nie są wyróżnione, ze względu na fundamentalną zasadę, jaką ma być ogólna współzmienniczość.

\section{Krytyka związku koncepcji struktury Frencha z neokantyzmem Cassirera}

French i Cei stwierdzają, że pogląd Cassirera na pierwotność relacji może być odseparowany od neokantowskiej doktryny ${ }^{77}$. Uważają oni, że wniosek o nieobiektowym statusie cząstek elementarnych (np. elektronów) nie wypływa z samego (neo)kantyzmu Cassirera $^{78}$. Pogląd, że neokantyzm Cassirera nie wpływa na jego wykładnię teorii naukowych i doktryny zasad jest, jak sądzę, chybiony. Związane jest to ze statusem zasad i rozumieniem obiektywności w ich kontekście.

Użyteczne może być porównanie Cassirera z wczesnymi zwolennikami logicznego empiryzmu. Wyjątkowy status zasad u Cassirera, np. ogólnej współzmienniczości, odróżnia go od innych wczesnych filozoficznych komentatorów OTW, zwłaszcza od M. Schlicka ${ }^{79}$. Dla tego ostatniego Zuordnung prowadziło jednoznacznie do empiryzmu/ konwencjonalizmu ${ }^{80}$. Przede wszystkim jednak Schlick, zgadzając się na utożsamienie obiektywności z niezmienniczością, znajdował w nim kryterium obserwowalności: zgoda wszystkich obserwatorów co do uzyskanego z różnych perspektyw pomiaru była podstawą do mówienia o obiektywności ${ }^{81}$. Dla Cassirera obiektywność związana z zasadą, na mocy której pewne wielkości są niezmiennicze, nigdy nie mogłaby być kryterium obserwowalności, ani w ogóle być związana z tym, co empiryczne.

(...) podstawową zasadę teorii względności - że uniwersalne prawa natury nie zmieniają swojej formy przy całkiem dowolnych przekształceniach zmiennych

\footnotetext{
75 Cassirer (1956): 467, zob. Ryckman (1999): 606.

76 Ihmig (1999).

77 French, Cei (2009): 114.

78 Ibidem.

79 Koncepcje Cassirera w wielu miejscach przypominają koncepcje neopozytywistów - Zuordnung przypomina definicje koordynujące, zaś aprioryczność zasad nie należy do porządku form naoczności, a do porządku form rozumienia - co umożliwia rewizję egzemplifikacji zasad. To z kolei przypomina koncepcję zrelatywizowanego a priori Reichenbacha, przedstawioną jednakże w jego bardziej kantowskim okresie twórczości.

80 Ryckman (2005): 28.

81 Friedman (1983): 25.
} 
przestrzenno-czasowych - można rozumieć jako twierdzenie analityczne; jako wyjaśnienie, co rozumie się przez „uniwersalne” prawo przyrody. Ale wymaganie, że w ogóle musi istnieć tego rodzaju ostateczna stała, jest syntetyczne ${ }^{82}$.

Już ujawnione zasady mają mieć charakter „logicznie konieczny”:

W rzeczywistości da się pokazać, że ogólna idea niezmienności i jednoznaczności pewnych wartości, która jest naczelną ideą teorii względności, musi w jakiejś formie powrócić w każdej teorii przyrody, ponieważ należy do jej logicznej i teoriopoznawczej istoty ${ }^{83}$.

Zuordnung Cassirera odpowiada za odnoszenie się teorii do świata, ale jest regulowane przez zasady, które mają gwarantować ciągłość i stabilność nauki.

Istnieje spór wśród badaczy myśli Cassirera co do tego, jak interpretować zasady - czy mają one charakter wyłącznie konstytutywny, wyłącznie regulatywny czy też należy je charakteryzować jako konstytutywno-regulatywne. Sądzę, że jest to kluczowe zagadnienie interpretacyjne w odniesieniu do problemu kompatybilności filozofii Cassirera z szerzej ujętymi poglądami zwolenników OSR.

Ryckman ${ }^{84}$ zaproponował, aby ogólną współzmienniczość traktować jako zasadę zarówno regulatywną, jak i konstytutywną. Wtóruje mu Heis ${ }^{85}$, dodając, że zasady ogólnie mogą być wg Cassirera zarazem konstytutywne i regulatywne. French i Cei stwierdzają, że

Przyjęcie odmiennego rozumienia praw może prowadzić do poglądu na obiektywność bliższego ideałowi klasycznych realistów, dotyczącemu dostępności niezależnego od podmiotu świata dzięki wiedzy, lecz w rozważanym poglądzie dostępność świata powiązana jest $\mathrm{z}$ fundamentalnie relacyjnym charakterem naszej wiedzy ${ }^{86}$.

Fundamentalnie relacyjny charakter naszej wiedzy nie jest jednakże warunkiem wystarczającym do utożsamienia ze sobą pojęć obiektywności i rzeczywistości. Cassirer, twierdząc, że OTW znajduje się na końcu szeregu teorii uogólniających zasadę względności, wydaje się traktować ogólną współzmienniczość jako konieczny wymóg formułowania kolejnych teorii fizycznych. W tym sensie ogólna współzmienniczość powiązana byłaby z postulatem normatywnym, o którym orzeka się logiczną konieczność. Wnosi się o tym na podstawie analiz poznania naukowego przeprowadzanych z perspektywy zmodyfikowanego funkcjonalistycznie transcendentalizmu. Prowadzi to do postulowania, aby teorie naukowe miały określoną własność formalną, gwarantującą ich adekwatność ze względu na zasady. Regulatywny aspekt zasad dotyczy pojmowania obiektywności jako własności formalnej. Uznanie zasad za konstytutywne

${ }^{82}$ Cassirer (2006): 51.

${ }^{83}$ Ibidem.

${ }^{84}$ Ryckman (2005): 46

${ }^{85}$ Heis (2014): 11.

${ }^{86}$ French, Cei (2009): 114, tłum. D.L. 
oznaczałoby, w kontekście teorii Cassirera, że zasady konstytuują właściwy obiekt poznania poprzez przekształcenia niezmiennicze.

Już samo rozumienie zasad jako zasad wyłącznie regulatywnych, bez motywacji neokantowskiej, może być kłopotliwe dla zwolenników OSR. Jeżeli bowiem French stwierdza, skądinąd słusznie, że praktyka naukowa (związana z fizyką teoretyczną) nie może rozstrzygać sporów metafizycznych ${ }^{87}$, to zasady regulujące tę właśnie praktykę również nie mogą tego uczynić. Sądzę jednak, że problem OSR w kontekście neokantyzmu Cassirera jest głębszy. Zgadzam się z poglądem, że trudno jednoznacznie ustalić, czy rozumiał on zasady tylko jako zasady regulatywne czy też tylko jako zasady konstytutywne. Przychylam się jednak do odczytania, wedle którego zasady, regulując sposób formułowania teorii naukowych, implikują swój aspekt konstytutywny. W świetle wypowiedzi Cassirera o ogólnej teorii względności, sformułowanie tej teorii jako ogólnie współzmienniczej sprawia, że na jej gruncie - dla Cassirera - niezmienniczość relacji czyni z nich obiektywny przedmiot poznania naukowego. „Logiczna konieczność” zasady sprawia, że niemożliwe staje się formułowanie obiektywnych treści poznawczych inaczej niż w kontekście teorii regulowanych daną zasadą: w tym sensie zasady również konstytuują możliwość takich treści. Prowadzi to do poglądu, że u Cassirera zasady mają charakter regulatywno-konstytutywny.

To jednakże jest niekompatybilne z podejściem zwolenników OSR. Skoro zasady u Cassirera są zarazem regulatywne, jak i konstytutywne, należałoby interpretować je jako odkryte w toku historycznego rozwoju nauki „logicznie konieczne” warunki formalne umożliwiające obiektywne poznanie naukowe. Jeżeli zatem French twierdzi, że treści niezmiennicze udostępniają nam obiektywny świat i twierdzenie to nazywa „warunkiem Cassirera”, to w świetle powyższych analiz „warunek Cassirera” jest czymś dokładnie odwrotnym od tego, co przedstawił sam Cassirer, u którego niezmienniczość zależy raczej od formalnie rozumianej obiektywności. French natomiast obiektywność zdaje się rozumieć jako bezpośrednio dotyczącą świata zewnętrznego, który udostępniają nam niezmienniki teorii i w tym sensie uzależnia obiektywność od niezmienniczości. Ten problem bierze się, ponownie, z utożsamienia "tego, co obiektywne” z „tym, co rzeczywiste", co w odniesieniu do myśliciela o neokantowskiej orientacji jest zdecydowanym nadużyciem interpretacyjnym.

\section{Zakończenie}

Zarówno w przypadku Poincarégo, jak i Cassirera skupiłem się na niekoestenstywności terminów „obiektywność” i „rzeczywistość”, którą wskazałem jako generator niekompatybilności poglądów tych myślicieli z propozycjami zawartymi w ESR i OSR. Inspiracje czerpane z tych myślicieli są zbyt swobodne na to, by zaliczać Poincarégo i Cassirera do tradycji realizmu strukturalnego. W związku z tym powoływanie się na odnośnych autorów powinno mieć w kontekście realizmu strukturalnego bardzo ograniczony zakres. Oznacza to tyle, że ESR, OSR i ich wariacje są stanowiskami sw oisty mi i do tego stwierdzenia prowadzi odrzucenie tezy o genezie realizmu strukturalnego. Uważam

${ }^{87}$ French (2014): 37. 
w związku z przeprowadzonymi rozważaniami, że koncepcja struktury przedstawiona u Frencha - sama charakterystyka bezobiektowej struktury jako ontologicznie samoistnej jest dalece niesatysfakcjonująca $\mathrm{i}$, jak sądzę, częściowo jest to powiązane z bezkrytycznym uznaniem tezy o genezie realizmu strukturalnego.

\section{Bibliografia}

Ainsworth P.M. (2010), What is Ontic Structural Realism?, "Studies in History and Philosophy of Modern Physics" 41 (1): 50-57.

Ben-Menahem Y. (2006), Conventionalism, Cambridge University Press, Cambridge.

Brading K., Crull E. (2017), Epistemic Structural Realism and Poincaré's Philosophy of Science, "Hopos: The Journal of the International Society for the History of Philosophy of Science" 7 (1): 108-129.

Busch J. (2003), What Structures Could Not Be, „International Studies in the Philosophy of Science" 17 (3): 211-223.

Cao T.Y. (2003), Can We Dissolve Physical Entities into Mathematical Structures?, "Synthese” 136 (1): 57-71.

Cassirer E. (2006), O teorii względności Einsteina, tłum. P. Parszutowicz, Wydawnictwo Marek Derewiecki, Kęty.

Cassirer E. (2008), Substancja i funkcja, tłum. P. Parszutowicz, Wydawnictwo Marek Derewiecki, Kęty.

Cassirer E. (1956), Determinism and Indeterminism in Modern Physics, Yale University Press, New Haven.

Chakravartty A. (2007), A Metaphysics for Scientific Realism. Knowing the Unobservable, Cambridge University Press, Cambridge.

Dasgupta S. (2015), Symmetry as an Epistemic Notion (Twice Over), „The British Journal for the Philosophy of Science" 67 (3): 837-78.

Demopoulus W., Friedman M. (1985), Bertrand Russell's The Analysis of Matter: Its Historical Context and Contemporary Interest, "Philosophy of Science” 52 (4): 621-639.

Dorato M. (2016), The Physical World as a Blob: is OSR Really Realism?, "Metascience” 25 (2): 173-181.

Dziekan M.R., Wobronie epistemicznego realizmu strukturalnego, „Lectiones \& Acroases Philosophicae" 7 (1): 89-112.

Esfeld M., Lam V. (2008), Moderate Structural Realism About Space-time, „Synthese” 160 (1): 27-46.

French S. (2014), The Structure of the World: Metaphysics and Representation, Oxford University Press, Oxford.

French S. (1998), On the Withering Away of Physical Objects, [w:] Interpreting Bodies - Classical and Quantum Objects in Modern Physics, E. Castellani (red.), Princeton University Press, Princeton: 93-113.

French S., Ladyman J. (2003), Remodelling Structural Realism: Quantum Physics and the Metaphysics of Structure, "Synthese" 136 (1): 31-56.

French S., Cei A. (2009), On the Transposition of the Substantial into the Functional: Bringing Cassirer's Philosophy of Quantum Mechanics into the Twenty-First Century, [w:] Constituting Objectivity. Transcendental Perspectives on Modern Physics, M. Bitbol, P. Kerszberg, J. Petitot (red.), Springer + Business Media B.V, Dordrecht: 95-116.

Frigg R., Votsis I. (2011), Everything You Always Wanted to Know About Structural Realism but Were Afraid to Ask, „European Journal for Philosophy of Science” 1: 227-276. 
Friedman M. (2005a), Ernst Cassirer and the Philosophy of Science, [w:] Continental Philosophy of Science, G. Gutting (red.), Blackwell Publishing, New Jersey.

Friedman M. (2005b), Ernst Cassirer and Contemporary Philosophy of Science, "Angelaki: Journal of the Theoretical Humanities" 10 (1): 119-128.

Friedman M. (1983), Reconsidering Logical Positivism, Cambridge University Press, Cambridge. Giedymin J. (1982), Science and Convention, Pergamon Press, Oxford.

Gower B. (2000), Cassirer, Schlick and "Structural" Realism: The Philosophy of the Exact Sciences in the Background to Early Logical Empiricism, "British Journal for the History of Philosophy" 8 (1) 2000: 71-106.

Heis J. (2014), Realism, Functions, and the A Priori: Ernst Cassirer's Philosophy of Science, "Studies in History and Philosophy of Science" 48: 10-19.

Hilbert D., Huggett N. (2006), Groups in Mind, „Philosophy of Science” 73 (5): 765-777.

Ihmig K. (1999), Ernst Cassirer and the Structural Conception of Objects in Modern Science: The Importance of the "Erlanger Program", "Science in Context" 12 (4): 513-529.

Ivanova M. (2015), Conventionalism, Structuralism and Neo-Kantianism in Poincaré's Philosophy of Science, „Studies in History and Philosophy of Modern Physics” 52: 114-122.

Langton R. (1998), Kantian Humility. Our Ignorance of Things in Themselves, Oxford University Press, Oxford.

Ladyman J. (1998), What is Structural Realism, "Studies in History and Philosophy of Science” 29 (3): 409-424.

Ladyman J., Ross D. (2007), Every Thing Must Go. Metaphysics Naturalized, Oxford University Press, Oxford.

Laudan L. (1981), A Confutation of Convergent Realism, „Philosophy of Science” 48 (1): 19-49.

MacLeod R. (1982), The "Bankruptcy of Science" Debate: the Creed of Science and Its Critics, 1885-1900, ",Science, Technology and Human Values" 41 (7): 2-15.

McArthur D. (2007), Recent Debates over Structural Realism, "Journal for General Philosophy of Science" 37 (2): 209-224.

McKenzie K. (2017), Ontic Structural Realism, „Philosophy Compass” 12 (4): e12399.

Mormann T. (2014), On the Vicissitudes of Idealism in 20th Century Philosophy of Science: The Case of Cassirer's Critical Idealism, "Lectiones \& Acroases Philosophicae” 7 (1): 47-62.

Musgrave A. (1988), The Ultimate Argument for Scientific Realism, [w:] Relativism and Realism in Science, R. Nola (red.), Kluwer Academic Publishers, Dordrecht: 229-252.

Newman M.H.A. (1928), Mr. Russell's “Causal Theory of Perception”, „Mind, New Series” 37 (146): 137-148.

Poincaré H. (1898), On the Foundations of Geometry, "The Monist” 9 (1): 1-43.

Poincaré H. (1902/1905), Science and Hypothesis, The Walter Scott Publishing Company, New York.

Poincaré H. (1905/1958), The Value of Science, Dover Publications, New York.

Psillos S. (2009), Knowing the Structure of Nature. Essays on Realism and Explanation, Palgrave Macmillan, Houndmills.

Psillos S. (2014), Conventions and Relations in Poincaré's Philosophy of Science, „Methode” 4 (3): 98-140.

Psillos S. (2015), Broken Structuralism, „Metascience” 25 (2): 163-171.

Putnam H. (1975), Mind, Language, and Reality, Cambridge University Press, Cambridge.

Russell B. (1927/2007), The Analysis of Matter, Russell Press, Nottingham.

Ryckman T. (1999), Einstein, Cassirer, and General Covariance -Then and Now, „Science in Context" 12 (4): 585-619. 
Ryckman T. (2005), The Reign of Relativity: Philosophy in Physics 1915-1925, Oxford University Press, Oxford.

Sady W. (2013), Spór o racjonalność naukowa: od Poincarégo do Laudana, Wydawnictwo Naukowe Uniwersytetu Mikołaja Kopernika, Torun.

Szlachcic K. (1992), Filozofia nauki francuskiego konwencjonalizmu: P. Duhem, H. Poincaré, E. Le Roy o poznawczych możliwościach nauk empirycznych, Wydawnictwo Uniwersytetu Wrocławskiego, Wrocław.

Szlachcic K. (2011), Prawda w perspektywie konwencjonalistycznej. Pierwsze historyczne diagnozy, [w:] Prawda, D. Leszczyński (red.), Wrocław: 345-361.

Szumilewicz I. (1978), Poincaré, Państwowe Wydawnictwo Wiedza Powszechna, Warszawa.

Torretti R. (1984), Philosophy of Geometry from Riemann to Poincaré, Kluwer Academic Publisher, Dordrecht.

van Fraassen B. (1989), Laws and Symmetry, Oxford University Press, Oxford.

Votsis I. (2012), Tracing the Development of Structural Realism, URL = http:/ / www.votsis.org/ PDF/Structuralism_in_Natural_Science.pdf [dostęp 15.01.2018].

Votsis I. (2005), The Upward Path to Structural Realism, „Philosophy of Science” 72 (5): 1361-1372.

Worrall J. (1989/1993), Structural Realism: The Best of Both Worlds?, [w:] The Philosophy of Science, D. Papineau (red.), Oxford University Press, Oxford: 139-165.

Worrall J., Zahar E.G. (2001), Appendix IV: Ramseyfication and Structural Realism, [w:] Poincarés Philosophy: From Conventionalism to Phenomenology, E. Zahar (red.), Open Court, Chicago: 236-251.

Worrall, J. (2011), Underdetermination, Realism and Empirical Equivalence, „Synthese” 180 (2): 157-172.

Zahar E.G. (1997), Poincaré's Philosophy of Geometry, or does Geometric Conventionalism Deserve Its Name?, „Studies in History and Philosophy of Modern Physics” 28 (2): 183-218. 